\title{
PENGARUH PEMBIAYAAN MUDHARABAH, MUSYARAKAH, MURABAHAH, DAN IJARAH TERHADAP PROFITABILITAS 4 BANK UMUM SYARIAH PERIODE 2013-2016
}

\author{
Purnama Putra \\ Maftuhatul Hasanah \\ Universitas Islam 45 \\ e-mail: purnama.p41@gmail.com
}

\begin{abstract}
This research employ quantitative descriptive method aimed at testing the effects of Mudharabah, Musyarakah, Murabahah, and ljarah Financings simultaneously and partially on the profitability of Sharia Banks in 2013-2016. This research uses secondary data taken from financial reports of Sharia Banks (Bank Umum Syariah/BUS) registered at the Bank of Indonesia. The data is analyzed using multiple linear regression. Four Sharia Banks were used as samples in this study which provide financial reports per three months. They are chosen using purposive sampling method. From the research result, it can be inferred that mudharabah financing does not have significant effect, musyarakah financing has significant negative effect, while murabahah and ijarah financings have significant positive effect by partially on profitability. Whereas simultaneously have positive significant to profitability.
\end{abstract}

Keywords: Mudharabah, Musyarakah, Murabahah, ljarah Fundings, Profitability, ROE

\begin{abstract}
ABSTRAK
Penelitian ini bertujuan untuk mengetahui pengaruh pembiayaan mudharabah, musyarakah, murabahah, dan ijarah terhadap profitabilitas Bank Umum Syariah yang terdaftar di Bank Indonesia Periode 2013-2016. Data yang digunakan adalah laporan keuangan Bank Umum Syariah (BUS) yang terdaftar di Bank Indonesia. Data dianalisis menggunakan regresi linear berganda. Sampel dalam penelitian ini sebanyak 4 Bank Umum Syariah, yang menyediakan laporan keuangan per triwulan. Sampel diambil menggunakan teknik pengambilan purposive sampling. Hasil dari penelitian ini menunjukkan secara parsial bahwa pembiayaan mudharabah tidak berpengaruh, pembiayaan musyarakah berpengaruh negatif signifikan, pembiayaan murabahah berpengaruh positif signifikan, pembiayaan ijarah berpengaruh positif signifikan terhadap profitabilitas ROE. Sedangkan secara simultan pembiayaan mudharabah, musyarakah, murabahah dan ijarah berpengaruh positif signifikan terhadap profitabilitas.
\end{abstract}

Kata kunci: Pembiayaan Mudharabah, Musyarakah, Murabahah, ljarah, Profitabilitas, ROE

Krisis yang melanda dunia sejak tahun 1998 telah menyadarkan banyak pihak bahwa perbankan dengan sistem konvensional bukan merupakan satu-satunya yang dapat diandalkan, tetapi ada sistem yang lebih tangguh karena menghadirkan prinsip keadilan dan keterbukaan yaitu perbankan syariah (Anjani dan Hasmarani 2016:175). Sistem perbankan syariah diatur dalam UU 
No.10 tahun 1998, yang merupakan undang-undang pengganti UU No. 7 tahun 1992. Sejak diberlakukannya undang-undang tersebut, perkembangan perbankan syariah di Indonesia cukup pesat. Apalagi sejak diberlakukannya UU No. 21 tahun 2008 tentang Perbankan Syariah yang terbit tanggal 16 Juli 2008 yang membuat pengembangan industri perbankan syariah nasional semakin memiliki landasan hukum yang memadai dan mendorong pertumbuhannya lebih cepat lagi. (Putra \& Silviana, 2017)

Buchori (2015) mengatakan sistem perbankan syariah di Indonesia 10 tahun terakhir telah berkembang secara signifikan. Total aset industri perbankan syariah telah meningkat hampir 13 kali lipat dari Rp. 21,5 triliun pada tahun 2005 menjadi Rp. 278,9 triliun pada tahun 2014. Laju rata-rata pertumbuhan aset perbankan syariah secara impresif tercatat mencapai 36,1\% sejak 2005-2014. Berdasarkan data yang didapat dari Bank Indonesia sampai dengan bulan Januari 2017, industri perbankan syariah telah mempunyai jaringan sebanyak 13 Bank Umum Syariah (BUS), 21 Unit Usaha Syariah (UUS), dan 166 BPRS, dengan total jaringan kantor mencapai 2.555 kantor BUS maupun UUS yang tersebar di hampir seluruh penjuru nusantara. (Putra \& Silviana, 2017)

Perbankan syariah memiliki beberapa produk yang merupakan produk unggulan dan banyak diminati oleh nasabah, pembiayaan mudharabah, musyarakah, murabahah dan ijarah mengalami peningkatan pada setiap tahunnya (Pernanu \& Putra, 2016; Faradilla, Arfan, \& Shabri, 2017). Pembiayaan mudharabah, musyarakah, murabahah dan ijarah yang disalurkan bank kepada nasabah/pengelola memiliki pengaruh yang besar terhadap perkembangan bank itu sendiri. Semakin besar pembiayaan yang disalurkan, maka akan semakin tinggi pula keuntungan yang diperoleh bank, sehingga dapat membantu dalam mengembalikan modal dan mendapatkan profit. (Rahayu et al., 2016:63).

Akad pembiayaan mudharabah, musyarakah, murabahah dan ijarah termasuk dalam akad tijarah digunakan dalam transaksi yang sifatnya komersil (profit oriented). Sesuai dengan konsep profitabilitas, bahwa salah satu yang mempengaruhi profitabilitas suatu bank adalah pembiayaan yang disalurkan oleh suatu bank. Jika tingkat pembiayaan tinggi, maka profitabilitas akan mengalami kenaikan, profitabilitas dapat diartikan sebagai salah satu indikator untuk menilai suatu kinerja perusahaan (Harahap \& Syafri, 2008).

Kajian terdahulu terkait pengaruh pembiayaan mudharabah, musyarakah, murabahah dan ijarah terhadap profitabilitas sudah banyak diteliti. Penelitian sebelumnya menggunakan uji parsial untuk pembiayaan bagi hasil mudharabah berpengaruh positif terhadap profitabilitas dikemukakan oleh Rahayu et al., (2016:4), Faradilla et al. (2017), Pratama et al. (2017), Kurniawan (2015), Wibowo dan Sunarto (2015), Rahmadi, (2017). Sedangkan pembiayaan mudharabah memiliki pengaruh negatif dan signifikan terhadap profitabilitas oleh Anjani dan Hasmarani (2016:182).

Penelitian terdahulu terkait pembiayaan musyarakah terhadap profitabilitas memperlihatkan pengaruh negatif terhadap profitabilitas dalam hal ini adalah ROE dikemukakan oleh Rahayu et al., (2016:4). Sedangkan pembiayaan musyarakah berpengaruh positif dan signifikan terhadap profitabilitas (Anjani \& Hasmarani 2016:182; Pratama et al, 2017; Permata el al. 2014). Serta pembiayaan musyarakah tidak berpengaruh positif signifikan terhadap profitabilitas Faradilla et al. (2017).

Beberapa penelitian terdahulu terkait pengaruh pembiayaan murabahah terhadap profitabilitas menyimpulkan bahwa pembiayaan murabahah tidak memiliki pengaruh terhadap profitabilitas (Faradilla et al. 2017; Anjani \& Hasmarani 2016; Reinissa, 2015; Muhammad, 2002; Sari \& Anshori, 2017). Percepatan pelunasan dalam pembiayaan murabahah akan mempengaruhi pendapat bank menjadi kurang maksimal, dan juga tingginya risiko gagal bayar mengakibatkan 
tingginya NPF (Non Performing Financing) yang menyebabkan kredit macet tinggi, dan dapat menyebabkan menurunnya laba sehingga berpengaruh terhadap turunnya profitabilitas (Putra \& Hasbiyah, 2017).

Bank-bank Islam yang mengoperasikan produk ijarah, dapat melakukan leasing, baik dalam bentuk operating lease maupun financial lease. Pembiayaan ijarah merupakan pembiayaan yang berprinsipkan sewa-menyewa. Bank sebagai pemilik objek sewa dan nasabah sebagai penyewa. (Emha, 2014; Faradilla, Arfan, \& Shabri, 2017; Putra \& Hasbiyah, 2017). Penelitian lainnya menemukan bahwa pembiayaan ijarah memberikan pengaruh positif signifikan terhadap profitabilitas (Emha, 2014; Pratama et al. 2017). Sedangkan Faradilla et al. (2017) menyatakan bahwa pembiayaan ijarah berpengaruh negatif terhadap profitabilitas.

Dalam riset uji secara simultan, Qodriasari (2014), Emha (2014) menghasilkan pembiayaan mudharabah, musyarakah, murabahah dan ijarah berpengaruh negatif signifkan terhadap profitabilitas, penelitian Anjani dan Hasmarani (2016) mudharabah, musyarakah, murabahah berpengaruh positif signifikan terhadap profitabilitas, sedangkan hasil riset Pratama et al. (2017) menyimpulkan pembiayaan mudharabah, musyarakah dan ijarah berpengaruh positif signifikan terhadap profitabilitas.

\section{METODE PENELITIAN}

Penelitian ini menggunakan metode deskriptif dengan pendekatan kuantitatif dengan analisis regresi berganda (Pernanu \& Putra, 2016; Silalahi, 2009). Teknik penentuan sampel dalam penelitian ini adalah menggunakan purposive sampling dimana peneliti memilih sampel berdasarkan tujuan penelitian dan kesesuaian kriteria-kriteria yang telah ditetapkan oleh peneliti. Riset ini menggunakan data sekunder yang berasal dari annual report yang diambil dari sumber www.bi.go.id, situs internet terkait penelitian, berbagai jurnal, dan buku-buku yang mendukung fokus riset ini. Populasi yang menjadi objek penelitian ini merupakan Bank Syariah yang terdaftar di BI sebanyak 11 bank syariah selama kurun waktu 2013-2016. Sedangkan sampel yang ditetapkan sebanyak 4 Bank Syariah dengan karakteristik sebagai berikut: (1) Bank Syariah yang terdaftar di BI dari tahun 2013-2016. (2) Bank Syariah yang mengeluarkan laporan keuangan per triwulan, karena untuk mengetahui informasi variabel independen yang akan diteliti. (3) Bank Syariah yang melakukan akad pembiayaan mudharabah, musyarakah, murabahah dan ijarah.

\section{Variabel penelitian}

Silalahi (2009:115) mengatakan variabel adalah satu konsep atau konstruk yang memiliki variasi (dua atau lebih nilai). Nilai yang melekat dalam variabel dapat berupa data ataupun angka. Adapun variabel yang digunakan dalam penelitian ini seperti pada Tabel 1.

Tabel 1. Definisi Variabel

\begin{tabular}{|c|c|}
\hline Jenis Variabel & Kontributor \\
\hline $\begin{array}{r}\mathrm{X}_{1}: \text { Pembiayaan } \\
\text { mudharabah }\end{array}$ & $\begin{array}{l}\text { Permata dkk (2014), Qodriasari (2014), Kurniawan (2015), Anjani } \\
\text { (2015), Wibowo (2015), Faradilla (2017), Pratama (2017) }\end{array}$ \\
\hline $\begin{array}{l}\mathrm{X}_{2:} \text { Pembiayaan } \\
\text { musyarakah }\end{array}$ & $\begin{array}{c}\text { Permata dkk (2014), Qodriasari (2014), Kurniawan (2015), Anjani } \\
\text { (2015), Wibowo (2015), Faradilla (2017), Pratama (2017) }\end{array}$ \\
\hline $\begin{array}{l}\mathrm{X}_{3}: \text { Pembiayaan } \\
\text { murabahah }\end{array}$ & Qodriasari (2014), Kurniawan (2015), Anjani (2015), Faradilla (2017) \\
\hline
\end{tabular}


Tabel 1. Lanjutan

\begin{tabular}{lc}
\hline \multicolumn{1}{c}{ Jenis Variabel } & Kontributor \\
\hline$X_{4}:$ Pembiayaan & Qodriasari (2014), Kurniawan (2015), Faradilla (2017), Pratama \\
sewa ijarah & (2017) \\
Y: Profitabilitas & Permata dkk (2014), Qodriasari (2014), Kurniawan (2015), Anjani \\
& (2015), Wibowo (2015), Faradilla (2017), Pratama (2017) \\
\hline
\end{tabular}

Sumber: Penulis, 2018

\section{HASIL DAN PEMBAHASAN}

Penelitian ini telah melalui uji statistik deskriptif dan uji asumsi klasik. Hasil uji yang dilakukan menunjukkan bahwa model yang diajukan dalam penelitian ini lolos dari penyimpangan asumsi klasik.

\section{Analisis Regresi Linier Berganda Variabel Dependen ROE}

Analisis regresi berganda merupakan teknik analisis data yang bertujuan untuk melihat besarnya pengaruh antar variabel-variabel independen terhadap variabel dependen, dan mengetahui besarnya nilai dari variabel dependen yang dijelaskan oleh variabel independen yang digunakan dalam periode penelitian (Rahayu et al., 2016). Variabel independen terdiri pembiayaan mudharabah, musyarakah, murabahah, dan ijarah variabel dependennya adalah profitabilitas (ROE). Adapun hasil pengolahan data adalah seperti pada Tabel 2 .

Tabel 2. Hasil Analisis Regresi Linear Berganda

\begin{tabular}{|c|c|c|c|c|c|c|}
\hline \multirow[b]{2}{*}{ Model } & & \multicolumn{2}{|c|}{ Unstandardized Coefficients } & \multirow{2}{*}{$\begin{array}{c}\begin{array}{c}\text { Standardized } \\
\text { Coefficients }\end{array} \\
\text { Beta } \\
\end{array}$} & \multirow[b]{2}{*}{$\mathrm{t}$} & \multirow[b]{2}{*}{ Sig. } \\
\hline & & $B$ & Std. Error & & & \\
\hline \multirow[t]{5}{*}{1} & (Constant) & $-88,128$ & 23,113 & & $-3,813$ & 0,000 \\
\hline & Mudharabah & 4,169 & 2,180 & 0,315 & 1,912 & 0,061 \\
\hline & Musyarakah & $-10,235$ & 2,136 & $-0,860$ & $-4,792$ & 0,000 \\
\hline & Murabahah & 6,779 & 1,887 & 0,513 & 3,593 & 0,001 \\
\hline & ljarah & 6,307 & 2,218 & 0,384 & 2,844 & 0,006 \\
\hline
\end{tabular}

a* Dependent Variable: ROE

Sumber: Hasil Output, 2017

Berdasarkan hasil pengolahan data pada Tabel 2, maka diperoleh persamaan regresi linear berganda sebagai berikut:

$$
Y=-88,128 a+4,169 \text { MDR - 10,235 MSY + 6,779 MRB + 6,307 IJR }
$$

Keterangan:
$A=$ Konstanta
MDR = Mudharabah
MSY = Musyarakah
MRB = Murabahah
IJR = ljarah 
Hasil persamaan analisis regresi linear berganda tersebut dapat dijelaskan melalui pernyataan sebagai berikut:

1) Konstanta sebesar $-88,128$, artinya nilai konstan ini menunjukkan bahwa apabila tidak ada variabel $\mathrm{X}=0$ maka profitabilitas akan menurun sebesar $-88,128$ atau jika pembiayaan mudharabah, musyarakah, murabahah, dan ijarah memiliki nilai konstan (0), maka nilai profitabilitas Return On Equity (ROE) menurun sebesar -88,128.

2) Nilai koefisien variabel mudharabah sebesar 4,169. Hasil ini menunjukkan bahwa adanya hubungan positif antara variabel mudharabah dengan profitabilitas ROE, semakin tinggi pembiayaan mudharabah, maka semakin tinggi pula profitabilitas ROE yang diperoleh.

3) Nilai koefisien variabel musyarakah sebesar -10,235. Hasil ini menunjukkan bahwa adanya hubungan negatif antara variabel pembiayaan musyarakah dengan profitabilitas ROE, semakin tinggi pembiayaan musyarakah, maka semakin rendah nilai profitabilitas ROE yang diperoleh.

4) Nilai koefisien variabel pembiayaan murabahah sebesar 6,779. Hasil ini menunjukkan bahwa adanya hubungan positif antara variabel pembiayaan murabahah dengan profitabilitas ROE, semakin tinggi pembiayaan murabahah maka profitabilitas ROE akan semakin besar didapatkan.

5) Nilai koefisien variabel pembiayaan ijarah sebesar 6,307. Hasil ini menunjukkan bahwa adanya hubungan positif antara variabel pembiayaan ijarah dengan profitabilitas ROE, semakin tinggi pembiayaan ijarah maka profitabilitas ROE akan semakin besar diperoleh.

\section{Uji Kelayakan model (Analisis goodness of Fit Model)}

Uji Analisis goodness of Fit Model bertujuan untuk mengetahui kelayakan model regresi berganda, apakah pengaruhnya signifikan atau tidak, maka taraf signifikansi yang digunakan sebesar 0,05 . Jika probabilitas $F$ lebih kecil dari 0,05 maka model regresi dapat digunakan untuk memprediksi variabel independen atau dengan kata lain variabel dependen secara simultan berpengaruh terhadap variabel dependen. (Siregar, 2013).

$\mathrm{F}$ tabel dalam pengujian hipotesis pada model regresi, perlu menentukan derajat bebas atau degree of freedom (df). Hal ini ditentukan dengan rumus df1 $=\mathrm{k}-1$ atau df1 $=5-1=4$ dan df2 $=\mathrm{n}$ $\mathrm{k}$ atau df2 = $64-5=59$ dimana $\mathrm{n}$ adalah banyaknya observasi kurun waktu data dan $\mathrm{k}$ adalah banyaknya variabel dependen dan independen (Anjani \& Hasmarani, 2016), dari rumus tersebut didapatkan hasil $F$ tabel 2,53. Dalam pengujian ini dilakukan dengan tingkat kepercayaan $5 \%$ atau 0,05. (Ghozali 2005:98)

Tabel 3. Hasil Uji Kelayakan Model (F-Test)

\begin{tabular}{|c|c|c|c|c|c|c|}
\hline Model & & $\begin{array}{l}\text { Sum of } \\
\text { Squares }\end{array}$ & Df & Mean Square & $\mathrm{F}$ & Sig. \\
\hline \multirow[t]{3}{*}{$\overline{1}$} & Regression & 10136,284 & 4 & 2534,071 & 12,302 & $0,000^{a}$ \\
\hline & Residual & 12153,152 & 59 & 205,986 & & \\
\hline & $\overline{\text { Total }}$ & 22289,436 & 63 & & & \\
\hline
\end{tabular}

a. Predictors: (Constant), ljarah, Mudharabah, Murabahah, Musyarakah

b. Dependent Variable: ROE

Sumber: Hasil Output , 2017 
Berdasarkan Tabel 3, nilai $F$ hitung sebesar (12,302), $F$ tabel sebesar $(2,53)$. Nilai $F$ hitung $(12,302)>F$ tabel $(2,53)$ dengan probabilitas sebesar $(0,000)$. Nilai signifikan $=(0,000)<(0,05)$, sehingga $\mathrm{H}_{0}$ ditolak dan $\mathrm{H}_{5}$ diterima, yang berarti model layak dan berpengaruh signifikan positif antara variabel independen dengan variabel dependen.

\section{Uji Koefisien Determinasi (R2)}

Koefisien determinasi ( $R$ Square) menunjukkan seberapa besar variabel independen menjelaskan variabel dependennya. Nilai $R$ Square adalah nol sampai dengan satu. Apabila $R$ Square sama dengan 1, maka persentase sumbangan pengaruh yang diberikan variabel independen dapat variabel dependen adalah sempurna, atau variasi variabel independen yang digunakan dalam model menjelaskan 100\% variasi variabel independen (Siregar, 2013).

Tabel 4. Hasil Uji Koefisien Determinasi

\begin{tabular}{ccccc}
\hline Model & $R$ & $R$ Square & $\begin{array}{c}\text { Adjusted } R \\
\text { Square }\end{array}$ & Std. Error of the Estimate \\
\hline 1 & $0,824^{\mathrm{a}}$ & 0,679 & 0,650 & 0,35037 \\
\hline
\end{tabular}

a. Predictors: (Constant), Mudharabah, Musyarakah, Murabahah, ljarah

b. Dependent Variable: ROE

Sumber: Hasil Output, 2017

Berdasarkan hasil perhitungan data pada Tabel 4, nilai $R^{2}$ ( $R$ Square) sebesar 0,679 yang berarti dukungan pembiayaan mudharabah, musyarakah, murabahah, dan ijarah terhadap tingkat profitabilitas ROE sebesar $67,9 \%$. Hal tersebut menunjukkan bahwa $32,1 \%$ dari sisa dukungan tersebut merupakan variabel lain yang tidak dimasukkan dalam model penelitian ini.

\section{Uji Signifikasi Parameter Individual}

Pratama et al, (2017) memaparkan, uji t digunakan untuk mengetahui seberapa besar tingkat signifikasi antara masing-masing variabel secara satu persatu atau parsial, dengan asumsi variabel lainnya konstan. Pada uji t dalam penelitian ini peneliti menggunakan taraf nyata lima persen $(\alpha=$ $5 \%$ ) untuk melihat nilai tingkat signifikansi dari masing-masing variabel independen. Jika nilai probabilitas lebih besar dari 0,05 tidak berpengaruh signifikan terhadap variabel dependen, tetapi jika nilai probabilitas kurang dari 0,05 maka signifikan terhadap variabel dependen (Emha, 2014).

Hipotesis yang akan diuji adalah:

$\mathrm{H}_{1}$ : Pembiayaan mudharabah berpengaruh positif signifikan terhadap profitabilitas.

$\mathrm{H}_{2}$ : Pembiayaan musyarakah berpengaruh positif signifikan terhadap profitabilitas.

$\mathrm{H}_{3}$ : Pembiayaan murabahah berpengaruh negatif signifikan terhadap profitabilitas.

$\mathrm{H}_{4}$ : Pembiayaan ijarah berpengaruh positif signifikan terhadap profitabilitas.

Hasil pengujian untuk variabel pembiayaan mudharabah, musyarakah, murabahah dan ijarah terhadap profitabilitas secara parsial terdapat dalam Tabel 5. 
Tabel 5. Hasil Uji Parsial (t-test)

\begin{tabular}{|c|c|c|c|c|c|c|}
\hline \multirow[b]{2}{*}{ Model } & & \multicolumn{2}{|c|}{ Unstandardized Coefficients } & \multirow{2}{*}{$\begin{array}{c}\begin{array}{c}\text { Standardized } \\
\text { Coefficients }\end{array} \\
\text { Beta }\end{array}$} & \multirow[b]{2}{*}{$\mathrm{t}$} & \multirow[b]{2}{*}{ Sig. } \\
\hline & & $\mathrm{B}$ & Std. Error & & & \\
\hline \multirow[t]{5}{*}{$\overline{1}$} & (Constant) & $-88,128$ & 23,113 & & $-3,813$ & 0,000 \\
\hline & Mudharabah & 4,169 & 2,180 & 0,315 & 1,912 & 0,061 \\
\hline & Musyarakah & $-10,235$ & 2,136 & $-0,860$ & $-4,792$ & 0,000 \\
\hline & Murabahah & 6,779 & 1,887 & 0,513 & 3,593 & 0,001 \\
\hline & ljarah & 6,307 & 2,218 & 0,384 & 2,844 & 0,006 \\
\hline
\end{tabular}

a. Dependent Variable: ROE

Sumber: Hasil Output, 2017

\section{Pengaruh Pembiayaan Mudharabah terhadap Profitabilitas ROE}

Berdasarkan Tabel 5 diketahui bahwa uji t yang telah dilakukan sebelumnya, menunjukan bahwa t hitung lebih kecil dari t tabel. Sehingga $\mathrm{H} 1$ ditolak, yang berarti variabel pembiayaan mudharabah berpengaruh positif tidak signifikan terhadap profitabilitas (ROE). Hasil ini sesuai dengan penelitian (Rahayu et al., 2016) yang membuktikan adanya pengaruh tidak signifikan profitabilitas (ROE). Pengaruh ini disebabkan karena nilai nominal pembiayaan yang disalurkan oleh Bank Umum Syariah mengalami peningkatan setiap tahunnya. Arah hubungan positif sesuai dengan penelitian (Faradilla, Arfan, \& Shabri, 2017). Pendapatan yang tinggi akan berpengaruh pada peningkatan laba bersih Bank Syariah. Kemudahan sistem bagi hasil dan persyaratan untuk mendapatkan pembiayaan mudharabah akan mempengaruhi minat nasabah untuk mengembangkan usaha kecil maupun menengah pada Bank Syariah.

Penelitian dilakukan oleh Reinnisa (2015), yang menunjukkan bahwa pembiayaan mudharabah tidak berpengaruh signifikan terhadap profitabilitas. Pembiayaan mudharabah tidak berpengaruh signifikan dikarenakan, mudharabah mempunyai risiko relatif tinggi karena adanya masalah ketidakpastian pendapatan keuntungan (return) dan masalah klasik principle agent problem. Sehingga ada kecenderungan bank kurang berminat menyalurkan pembiayaan dengan akad tersebut (Siregar \& llyas, 2002:67).

Secara teknis, akad mudharabah adalah akad kerja sama antara dua belah pihak, yang mana pihak pertama (shahibul maal) menyediakan seluruh modalnya, sedangkan pihak yang lain menjadi pengelola (mudharib). Keuntungan usaha secara mudharabah dibagi menurut kesepakatan yang dituangkan dalam kontrak, sedangkan apabila mengalami kerugian akan ditanggung oleh pemilik modal selama kerugian tersebut bukan akibat kelalaian dari si pengelola. Akan tetapi, jika kelalaian tersebut diakibatkan oleh kecurangan atau kelalaian si pengelola, maka harus bertanggung jawab atas kelalaian tersebut (Antonio, 2001: 95). Keuntungan atau nisbah bagi hasil pembiayaan mudharabah bersifat tidak pasti. Hal itu dikarenakan keuntungan atau nisbah bagi hasil ditentukan oleh Bank Umum Syariah sesuai dengan omset usaha yang diperoleh masing-masing bank. Meningkatnya usaha kecil dan menengah pada Bank Syariah akan mendatangkan keuntungan yang besar bagi pihak bank dan akan meningkatkan profitabilitas, sedangkan ketidakpastian pendapatan keuntungan membuat bank cenderung kurang berminat menyalurkan pembiayaan mudharabah. 


\section{Pengaruh Pembiayaan Musyarakah terhadap Profitabilitas ROE}

Berdasarkan Tabel 5 diketahui bahwa uji t menunjukkan bahwa thitung lebih besar dari t tabel, sehingga $\mathrm{H} 2$ diterima, dengan nilai koefisiensi menunjukan arah negatif, sehingga variabel pembiayaan musyarakah berpengaruh negatif signifikan terhadap profitabilitas ROE . Hal ini didukung dengan penelitian yang dilakukan oleh Rahayu et al., (2016) dan yang menyatakan bahwa pembiayaan musyarakah memiliki pengaruh negatif signifikan terhadap profitabilitas ROE.

Volume pembiayaan berbasis bagi hasil mempunyai arah dan pengaruh yang negatif terhadap kinerja Bank Umum Syariah. Hal ini berarti bahwa peningkatan dalam volume pembiayaan berbasis bagi hasil akan berpengaruh dalam menurunnya tingkat ROE Bank Umum Syariah. Hal ini sesuai dengan hasil penelitian yang dilakukan oleh Rahman \& Rochmanika (2012) yang menyatakan bahwa semakin tinggi tingkat pembiayaan berbasis bagi hasil akan menyebabkan semakin rendahnya tingkat profitabilitas Bank Umum Syariah.

Menurut konsepsi ideal, model pembiayaan Bank Syariah lebih diarahkan pada pembiayaan dengan prinsip bagi hasil yang menekankan pola hubungan kemitraan (partnership) antara bank dengan nasabah. Dimaklumi bahwa model pembiayaan bagi hasil yaitu mudharabah dan musyarakah mempunyai risiko relatif tinggi karena adanya masalah ketidakpastian pendapatan keuantungan (return) dan masalah klasik principle agent problem (Siregar \& llyas, 2002). Pengaruh signifikansi menurut Rahayu et al., (2016) karena pendapatan atau keuntungan yang diperoleh dari usaha sesuai modal yang disalurkan, apabila pendapatan musyarakah semakin besar maka dapat menurunkan besarnya tingkat profitabilitas. Hasil ini mendukung penelitian yang telah dilakukan oleh Oktriani (2008), dan Emha (2014) yang menunjukkan bahwa pembiayaan musyarakah berpengaruh terhadap profitabilitas.

\section{Pengaruh Pembiayaan Murabahah terhadap Profitabilitas ROE}

Berdasarkan Tabel 5 uji t yang telah dilakukan sebelumnya, menunjukkan bahwa $t$ tabel lebih besar dari t hitung, sehingga $\mathrm{H} 3$ diterima, dengan menunjukkan arah positif, sehingga dapat disimpulkan bahwa variabel pembiayaan murabahah berpengaruh positif signifikan terhadap profitabilitas ROE. Hal ini sesuai dengan penelitian yang dilakukan oleh (Kurniawan, 2015) dan (Azmi, 2016). Pembiayaan murabahah merupakan pembiayaan dengan porsi terbesar yang disalurkan Bank Umum Syariah kepada nasabahnya. Akad murabahah lebih banyak ditawarkan bank kepada nasabah karena akad ini memiliki tingkat risiko yang lebih rendah dari akad pembiayaan dengan basis bagi hasil. Margin keuntungan telah ditetapkan di awal akad, sehingga kepastian bank memperoleh imbal hasil jauh lebih mudah diprediksi.

Selain itu, pada akad murabahah tidak ada keharusan bagi bank untuk ikut mengawasi operasional kegiatan usaha nasabah sehingga biaya yang ditimbulkan atas aktivitas ini dapat dihindari. Dengan kepastian imbal hasil dan kemudahan dari sisi operasional besarnya pembiayaan murabahah yang disalurkan kepada nasabah terbukti berpengaruh positif terhadap profitabilitas Bank Umum Syariah (Azmi, 2016). Pembiayaan murabahah berpengaruh signifikan sesuai dengan penelitian (Oktriani, 2011). Pembiayaan murabahah secara parsial berpengaruh signifikan terhadap profitabilitas. Apabila pembiayaan murabahah pada bank dilaksanakan dengan baik, maka akan menyebabkan profitabilitas semakin baik pula.

\section{Pengaruh Pembiayaan ljarah terhadap Profitabilitas ROE}

Berdasarkan Tabel 5, diketahui bahwa t tabel lebih besar dari thitung, sehingga $\mathrm{H} 4$ diterima, yang berarti variabel pembiayaan ijarah berpengaruh positif signifikan terhadap profitabilitas ROE 
dan sesuai dengan penelitian yang dilakukan oleh Pratama et al., (2017). Semakin meningkat sewa ijarah maka semakin meningkat pula tingkat profitabilitas, sewa ijarah tiap periodenya mengalami kenaikan maupun penurunan. Kenaikan dan penurunan tersebut akan berdampak terhadap tingkat pendapatan bagi hasil dan pendapatan sewa sehingga akan menghasilkan laba lalu berdampak terhadap tingkat profitabilitas Bank. Sehingga pembiayaan ijarah berpengaruh signifikan terhadap profitabilitas ROE Bank Umum Syariah. Pengaruh signifikan didukung oleh penelitian (Eyda, 2015). Perkembangan pengaruh signifikan dikarenakan pembiayaan ijarah mengalami kenaikan setiap tahunnya.

\section{Pengaruh Pembiayaan Mudharabah, Musyarakah, Murabahah, dan ljarah Terhadap Profitabilitas}

Berdasarkan hasil pengujian kelayakan model regresi berganda Tabel 3, F hitung lebih besar dari $\mathrm{F}$ tabel, sehingga $\mathrm{H} 5$ diterima yang berarti model layak dan berpengaruh positif signifikan antara variabel independen dengan variabel dependen.

Hal ini menunjukkan bahwa variabel independen yaitu pembiayaan mudharabah, musyarakah, murabahah dan ijarah secara simultan mempunyai pengaruh positif signifikan terhadap variabel dependen yaitu profitabilitas Return On Equity (ROE). Hal ini sesuai dengan penelitian yang dilakukan oleh Emha, (2014) dan Pratama et al., (2017) yang menyatakan bahwa semakin meningkat pembiayaan mudharabah, musyarakah, murabahah dan ijarah maka semakin meningkat pula tingkat profitabilitas. Dimana pembiayaan mudharabah, musyarakah, murabahah dan ijarah tersebut merupakan produk yang banyak diminati oleh nasabah, karena dengan sistem bagi hasil akan memudahkan nasabah untuk mendapatkan pembiayaan tersebut, sehingga bisa memberikan kontribusi tingkat laba yang cukup besar bagi Bank Umum Syariah.

Menurut Permata et al., (2014) pengaruh positif signifikan dapat dilihat dari peran pembiayaan mudharabah dan musyarakah sebagai pembiayaan bagi hasil yang menyalurkan dananya untuk pembiayaan investasi. Pembiayaan tersebut akan menghasilkan keuntungan dan diperhitungkan berdasar rasio ROE. Begitupun murabahah dan ijarah pembiayaan ini cukup konsumtif digunakan masyarakat khususnya murabahah. Sehingga keempat pembiayaan ini saling mempengaruhi terhadap tingkat ROE dengan pendapatan yang diperoleh oleh masing-masing pembiayaan.

\section{PENUTUP}

Penelitian ini menyimpulkan bahwa pembiayaan mudharabah tidak berpengaruh terhadap tingkat profitabilitas, dikarenakan ketidakpastian pendapatan keuntungan dan tingkat risiko yang cukup besar membuat bank cenderung kurang berminat menyalurkan pembiayaan mudharabah, pembiayaan musyarakah berpengaruh negatif signifikan terhadap tingkat profitabilitas, hal ini disebabkan pembiayaan musyarakah mempunyai risiko yang relatif tinggi, ketidakpastian keuntungan dan masalah klasik dalam manajemen usaha, pembiayaan murabahah berpengaruh positif signifikan terhadap tingkat profitabilitas, hal ini disebabkan tingkat risiko yang lebih rendah dan pendapatan keuntungan yang jelas, pembiayaan ijarah, hasil penelitian ini menunjukkan pembiayaan ijarah berpengaruh positif signifikan terhadap profitabilitas, hal ini disebabkan tingkat risiko yang lebih rendah dan pendapatan keuntungan yang jelas. Secara simultan pembiayaan mudharabah, musyarakah, murabahah dan ijarah berpengaruh positif signifikan terhadap profitabilitas, sistem bagi hasil akan memudahkan nasabah dan sistem pembiayaan cukup konsumtif sehingga bisa memberikan kontribusi tingkat laba, yang mengakibatkan profitabilitas naik. 
Model penelitian yang relatif sederhana karena hanya mengungkap pengaruh pembiayaan mudharabah, musyarakah, murabahah dan ijarah terhadap profitabilitas secara parsial dan simultan, padahal terdapat faktor-faktor lainnya yang mempengaruhi profitabilitas seperti CAR, BOPO, NPF. Periode penelitian yang diambil relatif singkat periode tahun 2013-2016, padahal hasil penelitian dapat digeneralisasikan apabila melibatkan tahun pengamatan yang cukup panjang.

\section{REFERENSI}

Anjani, R., \& Hasmarani, M. I. (2016). Pengaruh Pembiayaan Mudharabah, Musyarakah dan Murabahah terhadap Profitabilitas BPRRS di Indonesia Periode 2012-2015. Syariah Paper Accounting FEB UMS, 175.

Antonio, M. S. (2001). Bank Syariah: Dari Teori ke Praktik. Jakarta: Gema Insani Pers.

Azmi, F. (2016). Analisis Pengaruh Volume Pembiayaan terhadap Profitabilitas dengan BOPO sebagai Variabel Moderasi pada Bank Umum Syariah di Indonesia. ISSN.

Buchori, A. (2015). Seri Edukasi Perbankan Syariah Produk dan Jasa Perbankan Syariah . Jakarta: Otoritas Jasa Keuangan (OJK).

Emha, M. B. (2014). Analisis Pengaruh pembiayaan Mudharabah, Musyarakah dan ljarah terhadap kemampulabaan Bank Mualamalat Indonesia. Jurnal IImiah Mahasiswa Ekonomi, Universitas Brawijaya.

Eyda, R. (2015). Pengaruh Pembiayaan Mudharabah, Musyarakah dan ljarah terhadap Profitabilitas Bank Syariah Mandiri Periode 2008-2013. Bandung: Universitas Widyatama.

Faradilla, C., Arfan, M., \& Shabri, M. (2017). Pengaruh Pembiayaan Murabahah, Istishna, ljarah, Mudharabah dan Musyarakah terhadap Profitabilitas Bank Umum Syariah di Indonesia. Jurnal Magister Akuntansi, 6(3), 10-18.

Ghozali, I. (2005). Aplikasi Analisis Multivariate dengan Program SPSS, edisi ketiga. Semarang: Universitas Diponegoro.

Harahap, \& Syafri, S. (2008). Analisis Kritis atas Laporan Keuangan. Jakarta, DKI Jakarta, Indonesia: Raja Grafindo Persada.

Kurniawan, F. P. (2015). Pengaruh Produk Pembiayaan Mudharabah, Murabahah, Musyarakah dan Qardh terhadap Profitabilitas BPR Syariah di Yogyakarta.

Muhammad. (2002). Kebijakan Fiskal dan Moneter dalam Ekonomi Islam. Jakarta: Salemba Empat.

Oktriani, Y. (2011). Pengaruh Pembiayaan Musyarakah, Mudharabah dan Murabahah terhadap Profitabilitas. Indonesia: Universitas Siliwangi.

Permata, R. I., Yaningwati , F., \& Z. A. Z. (2014). Analisis Pengaruh Pembiayaan Mudharabah dan Musyarakah terhadap Tingkat Profitabilitas (Return On Equity). Jurnal Administrasi Bisnis, Vol. 12, 3-4.

Pernanu, I. G., \& Putra, P. (2016). Pengaruh Motivasi dan Kepuasan Kerja terhadap Kualitas Pelayanan: Survey pada Karyawan BTN Kantor Cabang Syariah Kota Bekasi. Maslahah, 7(2), 15-32.

Pratama, D. N., Martika, L. D., \& Rahmawati, T. (2017). Pengaruh Pembiayaan Mudharabah, Pembiayaan Musyarakah, dan Sewa ljarah terhadap Profitabilitas. JRKA, Volume 3 Isue, 58.

Putra, P., \& Hasbiyah, W. (2017). Ekonomi Syariah. Jakarta: Akademika Presindo.

Putra, P., \& Silviana. (2017). Model Aida sebagai Strategi Pemasaran Bagi Nasabah Mengambang Perbankan Syariah (Survei Masyarakat Di Kota Bekasi). Jurnal Organisasi dan Manajemen, 13(1), 10-21. 
Qodriasari, I. L. (2014). Analisis Pengaruh Pendapatan Pembiayaan Mudharabah, Musyarakah, Murabahah dan Sewa ljarah terhadap Profitabilitas Bank Umum Syariah di Indonesia Periode Tahun 2011-2013. Skripsi. Universitas Muhammadiyah Surakarta.

Rahayu, Y. S., Husaini, A., \& Azizah, D. F. (2016). Pengaruh Pembiayaan Bagi Hasil Mudharabah dan Musyarakah terhadap Profitabilitas (Studi pada Bank Umum Syariah yang Terdaftar pada Bursa Efek Indonesia Periode 2011-2014. Jurnal Administrasi Bisnis, 61.

Rahmadi, E. (2017). Analisis Pengaruh Pembiayaan Murabahah, Mudharabah, Musyarakah, dan ljarah terhadap Tingkat Profitabilitas di Bank Umum Syariah Periode 2011-2016. Yogyakarta, Indonesia: Universitas Islam Negeri Sunan Kalijaga Yogyakarta.

Rahman, A. F., \& Rochmanika, R. (2012). Pengaruh Pembiayaan Jual Beli, Pembiayaan Bagi Hasil, dan Rasio Non Performing Financing terhadap Profitabilitas Bank Umum Syariah di Indonesia. Jurnal FE.

Reinnisa, R. (2015). Pengaruh Pembiayaan Musharabah, Musyarakah, dan Murabahah terhadap Profitabilitas Bank Syariah Mandiri. Skripsi. Malang, Indonesia: Universitas Brawijaya Malang.

Sari, W. D., \& Anshori, M. Y. (2017). Pengaruh Pembiayaan Murabahah, Istishna, Mudharabah, dan Musyaakah terhadap Profitabilitas (Studi pada BANK SYARIAH di INDONESIA Maret 2015Agustus 2016). Accounting and Management Journal, Vol. 1.

Silalahi, U. (2009). Metode Penelitian Sosial. Bandung: PT. Refika Aditama.

Siregar, M. E., \& llyas, N. (2002). Penempatan pada Aktiva Produktif Bank Syariah. Jurnal Ekonomi Syari'ah "MUAMALAH".

Wibowo, A., \& Sunarto. (2015). Pengaruh Pembiayaan Mudharabah dan Musyarakah terhadap Profitabilitas Perbankan Syariah (Studi kasus BPRS DI Yogyakarta periode 2012-2014). Menakar Peran Profesi sebagai Engine of Reform dalam Pembangunan Global Berkelanjutan, 115-124. 